\title{
The Dialogue Between Cinema and Philosophy: Hannah Arendt by Margarethe Von Trotta ${ }^{1}$
}

\author{
Alessio Tommasoli \\ Università Europea di Roma, Rome, Italy
}

\begin{abstract}
Hannah Arendt, the new film by the German director Margarethe Von Trotta, does not seem just like another trying to represent philosophy through the classic cinematic storytelling. It builds instead a perfect dialogue between these two practices that never encroach each other: There is not any doctrine that prevents cinema's freedom to create images and any philosophy claim that forces cinema to find in images an alternative way of expression. Von Trotta leaves any biopic form and stages a harmonic building where cinema fulfills philosophy and philosophy fulfills cinema. In this way she gets an outright practical exhibition of a theory, the "banality of evil". We want to comprehend the reasons of this perfect building analyzing this film, its characters with their acts, all the images, their montage, and editing, everything that supports the Arendt's philosophical notion. We work on the film with the philosophical categories created by Gilles Deleuze to study the history of cinema in two essays, Image-mouvement and Image-time. In this way we can unfold how Margarethe Von Trotta represents a theory through images, without any word as intermediary.
\end{abstract}

Keywords: Hannah Arendt, philosophy, Margarethe Von Trotta, Gilles Deleuze, film aesthethics, cinema

\section{Introduction}

The relation between cinema and philosophy has been once more subject of debate following the release of the movie by Margarethe Von Trotta on the 20th century's philosopher Hannah Arendt. The German director approaches the subject picturing the philosopher in her development as a thinker, how their thoughts were born, developed, and took shape.

If we consider the contemporary cinematic panorama, we can find several works which are built on a dialogue with philosophy, however, this is never so explicit.

Finding a clear and sensible relation between cinema and philosophy seems harder than in the past nowadays. This is probably due to the entertaining approach that cinema pursues in the western society; regulated by commercial reasons and consumerism, cinema tents to offer an entertainment which does not cost any mental effort to the audience, therefore it seems to take distance from philosophy which needs for its nature speculation.

\footnotetext{
1 This paper is translated by Valentina Maini.

Alessio Tommasoli, Ph.D. Student at Università Europea di Roma, Department of Philosophy, Assistant Professor in Moral Philosophy, Theoretical Philosophy and History of Modern Philosophy at Università Europea di Roma, Professor in Master of Practical Philosophy at Ateneo Pontificio Regina Apostolorum.
} 
However, we can still find some traces of this dialogue if we look at the linear narrative structure of most of mainstream movies which find their roots in the noble origin of cinema.

We are talking about some kind of roots derived from philosophy itself: the aesthetics, the matter of perception, the human sensibility towards images, and their composition in space and time.

This is exactly the matter analysed by Gilles Deleuze in his work dedicated to the cinema, Cinema 1: The Movement Image and Cinema 2: The Time Image. He shows how the seventh art cannot ever work without a continuous dialogue with philosophy, not even in its more commercial form. This is why the difference that he makes between movement-image and time-image is so crucial: It is not just a different way of editing that distinguishes narrative and experimental cinema, there is something more.

Since the first movie by Lumiére, L’Arrosseur Arrosée (1889), the cinematographic image has always been built on a theoretical construct who offered it, in one way or another, to the sensibility.

Nevertheless, the dialogue between cinema and philosophy seemed to fail exactly when this different kind of image opened the cinema productions: the movement-image created a narrative cinema addressed to the masses, whereas the time-image gave birth to some original and exclusive experimentations that we called the avant-gardes.

However, Deleuze himself explains that this discrepancy is just illusory and the use of the cinematic images does not weaken the dialogue between cinema and philosophy because the movement-image needs to build its structure starting from concepts even when their use is commercial and consumeristic.

In fact, if we look at this type of image, although its experimental approach is less evident compared to the time-image, we can still find some wonderful pieces of art in the mainstream cinema, mentioning for example Alfred Hitchcock.

We cannot deny that time-image cinema has a higher capacity of experimentation, but Hitchcock's films fulfilled, as Deleuze said, the movement-image bringing it closer than ever to the time-image. Deleuze talked about Hitchcock's production as the one which builds the movement-image through the relation-image in a way that succeeds in bringing out the mental aspect of the time-image.

This is exactly what we find in Margaret Von Trotta's Hannah Arendt: The realization of the movement-image, as we will explain, based on the dialogue that her cinema builds with philosophy.

Von Trotta undertakes a hard work: bringing a theoretical reflection inside the narrative contingency of images. Surely she is not the first director who attempts that.

Liliana Cavani and Giuliano Montaldo put forward a similar attempt but they inevitably had to delimit the philosophical thought and the biography of its thinker in a specific time frame. ${ }^{3}$

The main difference between these two directors and Margarethe Von Trotta is that the latter does not constrain her work but she intentionally sets her film inside a "plane of immanence" pictured by the

\footnotetext{
2 This movie was filmed in only one framing, with no cuttings or editing, and it's original title was Le Jardinier. It is not just a shot, but Lumiére's brothers tried to tell a story: A boy pranks a gardener stepping on the hose reel so to stop the water and soaking the man once he jumps away. It is considered as the first commedy of the cinema history because of its logical structure made on a beginning and an end.

${ }^{3}$ Giordano Bruno by Giuliano Montaldo, Beyond Good and Evil (Al Di Là Del Bene E Del Male) and Gallileo by Liliana Cavani. The first one seems closer to the Von Trotta's Hannah Arendt more than others because it is based on the movement-image. Beyond Good and Evil seems closer to a time-image structure indeed.
} 
movement-image. The effort that she makes does not use indeed the image-time and so she makes us clear that we do not need at all this kind of images to have a dialogue between cinema and philosophy. Surprisingly, Hannah Arendt shows how the cinematographic representation of a philosophical though can be fulfilled by the non-poetical form of image-movement.

Once more, we need Gilles Deleuze's categories to find an explanation to this unexpected conclusion. We have to refer to one of his last essay written together with Felix Guattari in 1991; in What Is Philosophy? Deleuze explains that philosopher has a way of thinking and writing given by the time and place they live, the books they read, their affinities and their idiosyncrasies. This means that a philosopher is an artisan of theoretical constructs and, consequently, that their history and their life cannot be separated from them. In this way the philosophical activity is on a "plane of immanence" that undermines three traditional ideas in philosophy: the one that considers philosophy as contemplation, the one that considers it as communication, and the last one that considers it as reflection.

Those three ideas prevent philosophy from showing its contingent feature of "real creator of concepts". As Deleuze explains, this ability of creation is strictly connected to contingency and it allows philosophy to make contemplations, communications, and reflections. The creative ability of philosophy can work against chaos giving it an order and a sense strong enough to survive far from the illusion of the opinion. In this way, philosophy produces (or, better, forges) concepts, such as science produces propositions and art produces artworks.

Philosophy, science and art: The three branches of knowledge identified by Deleuze are seen as three different disciplines which can individually create something while influencing each other and contributing to each result.

We can get an example of this mutual influence taking a look at the relation between cinema and philosophy. As philosophy stands on the plane of immanence, it can absorb affections and perceptions of cinematographic images in order to elaborate concepts, in the same way cinema can absorb philosophical concepts in order to create a cinematographic work. This is why we can see a philosopher as an artist and a director as a philosopher; they are both involved in a similar creative process.

Margarethe Von Trotta's Hannah Arendt seems to be the perfect realization of this mutual influence between cinema and philosophy: The genesis of the philosophical concept of the "banality of Evil" stands out from the images offering the audience the chance of contemplation, communication, and especially of reflection.

Such an amazing outcome is the result of a piece of work made on the movement-image: It recalls the same ability that Hitchcock had, but it values more that sense of contingency in the dialogue between philosophy and cinema.

In order to deeply understand this aspect we need to analyse the work by Von Trotta applying to it Deleuze's categories on cinema, this without losing sight of the unity of its structure.

Even if nobody could ever know how much she was aware of doing something like this, Margarethe Von Trotta seems to work with the Deleuze teaching to show a philosophical theory in a film: She represents the genesis of the "banality of Evil”, building its creation. The director's intention is indeed setting the philosophical reflection on an authentic plane of immanence made of the time and place lived by Hannah Arendt, with all her existential, intellectual and daily experiences, her public, private, and social life. This can explain why the title of 
the movie is simply: Hannah Arendt. In this way the scenes of the movie represent theoretical concepts with the essential support of history and biography. As a structure of the movie Von Trotta chooses a triangle, an elementary geometrical shape which well fits with the purpose of the movie.

The director forms this triangle setting three characters at the three points of it: Adolf Eichmann, Martin Heidegger and the main character such as Hannah Arendt. The disposition of these points is definitely not accidental; the higher point, the German philosopher, is the peak of the triangle that points down to the lower segments composed by its two extreme points, Eichmann and Heidegger. In this way Hannah Arendt is the film's driving force: a tangible point where two irreconcilable planes join together. At the base of such a triangle we have Adolf Eichmann (in a cliché form) and Martin Heidegger (via flash-back), two "ghosts” who interacts with the only real image, Hannah Arendt.

The crucial event which inspires the concept of the "banality of Evil” is the Eichmann's trial: Von Trotta shows it through some television and archive images, pieces of videos which are intertwined with the narrative flow of the movie. Those are exactly the types of images that Deleuze calls "cliché", images like metaphors, sensory-motor images of a thing that suggest a perspective (partial and fraudulently exploited) while hiding its essence. Therefore, "cliché" are images linked to a stereotype, a preconception, who appear as fluctuating and anonymous images that go around the world outside living on the unclear surface of current events, such as news, chronicles, interviews, jingles among political, social, or historical events. This kind of images simply touches lightly the characters but still hits their intimate parts with prejudices and commonplaces.

\section{The First Triangle Point: Adolf Eichmann}

That is exactly the intention of Von Trotta: representing Eichmann with archive images so to make him a cliché in the same way mass media did turn him into a "monster", the face of the authentic Evil.

Every Eichmann appearance exhibits the director's intention through which she offers the Eichmann-cliché to the Hannah Arendt's thinking in order to make an elaboration of it. In this way Arendt is able to start her intellectual activity: tearing off the cliché from Eichmann like we tear off the metaphor from the material thing. Inside the film process, cliché image breaks opening to the whole image with her essence, spirit, being. Without any metaphor Von Trotta creates a pure image so to let "rise the thing itself, full of its beauty or horror excess, full of its radical or inexcusable disposition, because it doesn't need to be justified, for better or worse” (Deleuze, 1983, p. 32). ${ }^{4}$ Here we can find the intention of the director which slowly unveils the concept of the "banality of Evil”.

By depriving Eichmann of its label of monster Arendt can overcome what Bergson calls "habitual or automatic recognition" which belongs to the society of cliché, Arendt offers instead a critical thought based on "attentive recognition". Thus Arendt can keep a critical though leaving the common opinion about Eichmann.

She keeps him to be the same but she lets him pass through all the different stages that Arendt herself goes through. The Von Trotta's Arendt is above all a "soothsayer”, a "seer” while she goes beyond the cliché’s culture discovering what it hides. She is more than an active character able to fight against cliché defending herself from the outside common opinion.

\footnotetext{
${ }^{4}$ The citation is translated by the author of the paper.
} 
When Deleuze talks about cliché, he defines it as a component of the traditional cinematographic image crisis, which is the action-image.

This crisis was born exactly when cinema started to emulate the 20th century's literature trend: undoing completely plot and narration and rendering them a broken line of facts, wandering fragments which prevent any attempt of foreseeing the events.

One of the causes of this crisis is according to Deleuze, the passive behaviour of the characters in facing the events: The characters seem just to pose on the scenes without neither being the sufferers nor the actors in the action.

In such a situation, with no plot unity and action from the characters, the cliché becomes the link, the basic component that keeps the parts together thanks to its ability of coming inside each character to build their inner world.

But if in this crisis of the action-image the category of cliché was used to denounce the passiveness of the characters, here in the Von Trotta's Hannah Arendt, it is indeed the gear able to highlight the intellectual activity of the German philosopher.

The strength of the Eichmann-cliché could not have been more representative. Each archive’s scrap image displays in a ruthless way his nature: set phrases and contradictions, show the averageness, the inferiority complex, the empty integrity filled with an uncritical submission in front of the orders. Arendt put emphasis on this fighting against the prejudice that depicts him as a "monster", she shows all the unspeakable banality of a person with no imagination (not intelligence) to understanding his acts and their consequences. Hanna Arendt is devastated by a human image so unable to acknowledge its responsibility and she is devastated once taking over that responsibility and denouncing the conspiracy made of a dangerous cliché moved by ideological beliefs and justified by philological necessities.

Beyond Arendt's thinking work about the Eichmann-cliché, the cliché itself works at the same time on Hannah Arendt, because, as we said, it is not possible working on it by sparing its penetration. This is why cliché has such a huge symbolic meaning in the Hannah Arendt's plot: It is the moment when the main character starts reacting, the zero-hour as the beginning of a feedback. ${ }^{5}$ We can find here what Deleuze calls the "small form" of the action-image: It begins from a starting action that generates a situation able to produce a different action as a reaction. In Von Trotta's film the starting action is the Eichmann trial that generates the cliché situation able to produce the Arendt reaction: the destruction of the cliché through a critical thinking.

At the same time, such a critical thinking seems to create the other form of action-image too, the "big form": on the contrary, this begins from a given situation that produces a reaction able to change the initial, starting situation. If we analyse the film's structure, we can find its components exactly in Arendt's critical thinking: Through the Banality of Evil article she explains a given situation that produces a reaction from the critics which produces a new situation where it is questioned and overturned not just the Arendt's theory but her entire life as a women and philosopher.

Through the passage from the "small form" to the "big form", Von Trotta seems to provide her work with that key element which entangles the Arendt's thought with her own existence putting philosophy in a real plane of immanence thanks to a theoretical concept.

${ }^{5}$ Deleuze called it “caesura” in Deleuze, G. (2004) Fuori dai cardini del tempo. Lezioni su Kant (1978), Milano: Mimesis Edizioni. 
The action of the cliché can make anybody who owns it as a cliché herself among other clichés, thinking and feeling herself and the world around through them. Von Trotta's Arendt makes a revolution uprooting cliché with her critical conscience so to think and feel herself no longer through it, but in an incisive connection with it that let her flee from the human destiny of being herself a cliché.

Therefore, Eichmann seems to be the best historical "picklock" at the service of a philosophical thinking. Sure enough this character generates a theoretical and existential interest in Hannah Arendt as she faces his deceit: His plain normality denies any inhuman monstrosity making of him an ordinary man, like any human being could be. This is the reason why an unbearable game of attraction and repulse starts between Eichmann and Arendt triggering a process of identification from which follows a critical reflection.

In this relation we can see the intersection inside the movie structure which links the higher point (Arendt) and one of the two lower points (Eichmann), composing the first perpendicular segment of the triangle.

It is exactly at this stage that Arendt starts reflecting on the inseparable link between Evil and the lack of responsibility, the starting point which will lead to her conclusion; the "banality of Evil" as a "will-not-to-know" easily falls on power exploitation, generating, among the different possibilities, a totalitarian regime.

We can see here a new transition to a different type of the cinematographic image. The first establishment of the "banality of Evil" concept is strictly connected to the reflection-image: By this name, Deleuze calls that transition from action-image to relation-image which takes place when an action and a situation begin to have an indirect proportion.

As we can see, the action is the Arendt philosophical construct and the situation is the whole fact around it, the intellectual environment, its historical, social, and politic influences, the personal life and her academic work: It is exactly when these two aspects of her life starts taking different directions and creating tension that her philosophy climbs a new level.

Therefore, the thinking action recognizes what Deleuze calls "figures" that are "pure images" torn off from cliché and inserted directly in an attract/repulse mechanism.

Von Trotta offers a virtual image, the Eichmann-cliché, to Arendt's thinking that makes of it an actual image. But differently from Deleuze's theory, the virtual image here does not have that fundamental nature which belongs to the time-image. The virtual image in Hannah Arendt is just a tool able to fulfill the movement-image that is the basic of the traditional cinema. This is the reason why this virtual image is never actual in itself but it functions following the concept of the "banality of Evil".

\section{The Second Triangle Point: Martin Heidegger}

The same operation has been applied by Von Trotta to the character of Martin Heidegger.

His presence in the movie is given in just three short flash-backs. He plays through that an ambiguous role and he is far from being a simple mentor or lover. It is just his ambiguity that plays such an important part in the life of Hanna Arendt, as Von Trotta seems to suggest.

According to the categories put forward by Deleuze, a flash-back is a virtual image that he defines image-souvenir: This category owns an essential value in the creation of a critical thinking.

As we have previously seen with Eichmann, in order to generate this critical thinking we need to use Bergson's distinction between "habitual recognition” and "attentive recognition”; if Hanna Arendt used her 
descriptive ability to deprive Eichmann of his cliché, she seems to do it once again with Heidegger by actualizing the virtual image of his flash-back footage.

As we previously said, the actual image given by Von Trotta represents the concept of "banality of Evil" in its genesis and is simultaneously developed with the Arendt's theoretical action.

This action has already produced the result of separating the image of Eichmann from his cliché in order to make of it a pure image; the same operation is here applied to the virtual image of Heidegger which, once actualized and made pure, can perfectly fit into the attract/repulse mechanism. As per Eichmann, this mechanism can take place via an extension of the memory perception which allows the object (Heidegger) to remain the same even if going through different planes, the Arendt's existence and the integrity, both connected into the "banality of Evil” construct.

Now the importance of Heidegger flash-back is clear: We can analyze the functionality of the reflection-image. As we already explained, it is not a realization of Arendt's thinking action, but a basic ride of it: Reflection-image allows to translate the action-image in a relation-image but not to its completely fulfilment. So that Heidegger's character leads the Arendt thinking over the action, but still not in a definitive relation.

Once again we can notice that virtual images (cliché and flash-back) do not have here the same basic nature that they feature in time-images; they are instead used by Von Trotta as some sort of tools offered to a relation-image in order to accomplish the entire movement-image on which the director bases her cinematographic artwork.

For this reason then Heidegger's character seems to enrich the Arendt's identity digging in her past to strengthen her conscience through an attract/repulse feeling.

Such a "ghost" coming from an untamed past silently gets into Hanna Arendt's life and inevitably influences her philosophical thinking. In fact Von Trotta does not linger on a hypothetical love story between the two philosophers but emphasizes Heidegger in his role of transmitting a crucial enrichment to Hanna and her thinking.

Following this path we can see that where Eichmann represents the absolute emptiness of a conscious presence, Heidegger is just the refusal of that presence forsaken into silent.

In its ambiguous role of mentor, Heidegger allows to Arendt's reflection to trace a border between the two philosophical theories, her own and her professor's one. They are two ideas born in a common background which then take two completely different directions once facing the matter of responsibility. It is exactly on this matter that an existential choice is required, the philosophical step that allows to pass from the theoretical plane to the practical and ethical plane. Heidegger is unable to climb this step, this is why in the movie he is seen more as an absence than a presence, as a consciousness without body, subtracting himself from taking that step. He does not choose therefore condemn himself to an exile from responsibility.

Such an ambiguous mentor lets the Arendt's thought to draw a line between these two different philosophical ideas. That is the reason why for the second time the protagonist finds in front of her a zero-hour: Where Eichmann is the first who leads her towards an exterior reaction, Heidegger triggers in her an inner reaction between the protagonist's conscience and her thought. She has to make a choice: jumping or standing still. Once again the director gives us the picture of a character free to choose its relation with a virtual image, either succumb to it or face it. 
The Heidegger flashback is exactly what allows Arendt to make her choice: It is not just a past that enriches the present, but it gives her the time frame and spiritual strength to connect her conscience and her philosophical construct. Von Trotta seems to understand the Deleuze's teaching: In order to understand the genesis of a concept we need to analyze it in the plane of immanence set in a time frame.

Thanks to the Heidegger's character, the director can actually show the genesis of the "banality of Evil" concept and the seed of integrity entrenched in its thinker's past. As Deleuze says, memory can recall the past to a future purpose only if it was already alert in the moment in which past was still present (Deleuze, 1983, p. 46).

Von Trotta suggests that Arendt's integrity was born when she was still a student and this is why it can turn into memory now. Through this integrity everything seems to find its actualization: All the virtual images become part of Arendt's present, part of her contingent thought and part of the situation around it. All this in order to produce an active present where movement-image can finally turn firstly into a reflection-image and secondly into a relation-image completely fulfilled.

Now if we watch the movie reflecting on the triangle shape, we can see that each vertex is well defined: Hannah Arendt on the top, Eichmann and Heidegger at the base as two opposite points of the geometrical figure.

Ultimately, we need to understand how Margarthe Von Trotta draws those lines and close that geometrical shape creating a triangle.

As we already said, the final moment for the realization of the artwork is the relation-image. Through it the German director gives to her film the power of representing a philosophical concept in its active concreteness, in its making off, development, and fulfillment.

So, by analyzing Eichmann and Heidegger characters, we said that Arendt deals with them through an incisive thinking action (“attentive recognition”) which enables her to face them in a critical relation. It is exactly this ability of the protagonist and her dominant position that allows the feasibility of the general structure of the whole movie based on the relation-image.

Deleuze talks about a fundamental aspect of this kind of image that he defines "mental”. He explains that it is already a part of the action-image, but as something that allows the possibility of the action. It is not the fulfilment of the action-image because this cares just about the action result and reactions to it. The main aspect of the relation-image is exactly the action reason, something that mind collects to make an elaboration. Deleuze talks about the "dual", two terms able to fulfill themselves in an action/reaction movement of the action-image. Contrary, in the relation-image these terms single out a third term, the "mental" which is an independent term, outer from the others. It does not inspire actions, explains Deleuze, but inspires acts able to build a relation among its own terms. Such kinds of acts are the "intellectual feelings" of relations that are interpretations. Therefore the relation-image has its specific field: It takes independent thinking objects and thinks about them in order to make relations out of them, symbolic acts and intellectual feelings.

Von Trotta's Hannah Arendt makes relation as a discussion of two different terms. It seems possible thanks to what Deleuze calls "symbol" that is "the situation where we are inspired comparing two arbitrarily unified images so to build them in a whole” (Deleuze, 1983, p. 46).

These arbitrarily unified images are exactly the "figures" of Adolf Eichmann and Martin Heidegger: Arendt builds them in a whole in spite of their different nature. These "figures" represent the interior movement of the whole, of the "banality of Evil" concept that changes in order to allocate them. 
The movement-image structure explained by Deleuze can help us to understand Hannah Arendt structure. The movement-image has two faces: One of the objects that identifies a space movement changing their partial location, and one of the whole that identifies a temporal movement changing in an absolute way. In Hannah Arendt, the first one is pictured by the Eichmann and Heidegger characters and the second one by the "banality of Evil” philosophical concept.

Therefore the relation-image is the fulfilling of all the images displayed by Margarethe Von Trotta. It is the realization of the action-image and of the reflection-image too, so to give sense to all their parts through the actualization made from the "banality of Evil" mental elaboration. This happens even if, as we said, this concept takes part to the same elaboration, to change itself following the same parts it works on. That is the reason why such a relation does not have any real field, because the elaboration is not made on any preconception. The "banality of Evil" concept allows the realization of the Eichmann and Heidegger's description as they allow the realization of the "banality of Evil" concept.

We can see that the Arendt philosophical action on Eichmann and Heidegger, the reflection-image that organizes the final relation-image, shows a connection between lack of integrity and cruel consistency of its own role. Therefore, the difference between a Nazis functionary who thoughtlessly obeys orders and a high-brow who obeys his thinking away from facts seems so slight, so indiscernible.

Such a dramatic lack of difference is the beginning of the Arendt relation on the objects and on the whole, on the Eichmann-Heidegger couple and on the "banality of Evil" concept. Here we can see the genesis of the relation-image and the origin of the cinematographic and philosophical meaning in which Von Trotta's artwork has its realization. This kind of image definitely fulfills the philosophical thinking through the realization of the Eichmann-Heidegger-Arendt triangle: Such a geometrical shape becomes the tangible form of "banality of Evil", its root and its meaning. The relation-image can unify the three triangle points in a perfect cinematographic geometry: Two points on the base segment, two different images have a relation thanks to the third vertix on the top of them, the protagonist with all her existential experience who draws the segments through a mental action. By unifying all the points she generates a symbolic whole.

\section{The Third Triangle Point: Hannah Arendt}

Placed in a classical philosophical thinking, this triangle would not have any tangible segments, because they would be like some rays of light spread down from a higher point through a pensively gaze. But in the Von Trotta's cinematographic structure it has the extension of a body, its specific weight and material contingency. It is exactly the surplus value of Hannah Arendt: The "banality of Evil" concept is on a "plane of immanence".

If we watch carefully, we cannot find any image that hides the protagonist tenaciousness, its perseverance to defend the coherence of a jump from theory to practice, the existential pain suffered to keep the inviolable responsibility of its thought. Von Trotta looks with her cinematographic eye inside the essence of an intellectual resistance and of its inevitable sacrifice: Arendt's deepest and longest friendships spoiled, the academic career damaged, the social and intellectual trust injured. Here we can see the marks of martyrdom, maybe the last made in the name of freedom of thought.

As we explained, Arendt fights for her integrity. And her unspoken fighting stays afloat throughout the film as the reason of all the relations she has with the world around. She does not try to change her ideas from the Hans 
Jonas' hurting criticism, her closest friend. He blames her of turning Shoah into a philosophical matter. Nevertheless she faces the accusations as if she knows since the beginning that she has to pay a hard price to defend her integrity. So she cannot come to any compromise, because the compromise itself is exactly that banality at the origin of the Evil.

Arendt understands that is impossible not to make a choice: Even if you think you are not choosing, that is a choice. But every choice begins where responsibility begins. So who does not choose has their responsibility. By avoiding their responsibilities they give up their integrity.

Each Von Trotta's image is a part of a divided whole that Arendt's thinking has to connect. Therefore, the lack of integrity of those who do not choose stays afloat through the film. It takes part on the protagonist's theoretical thinking, on her life and her conscience too.

Thinking and existence become just one thing, so real to be a matter of life and death.

During the film Von Trotta's Arendt gets a sense in an intellectual and social way. But above all she gets a sense in her existential condition.

\section{Conclusion}

We can understand now that the realization of the movement-image fulfilled the film: It can show a theoretical construct in a concrete form. Deleuze reminds us that the movement-image structure is based on the relation-image: The latter puts the final touch on any other image. In this way the relation is the interpretation of all images which makes the plot of the cinematographic artwork.

As we told at the beginning, Deleuze says that this kind of cinema based on the relation-image has been fulfilled by Alfred Hitchcock. For the first time ever, the British director offered the action of relation to the cinema audience, making them a part of the film. In this way the audience has to make a mental elaboration of the several "figures". They get into the movie and this is possible just for one reason: They have to empathize with the main character.

Hitchcock displayed a protagonist that had not the freedom of movement, like happened to the Rear Window's protagonist. The cinema viewer was able to empathize with such a character more than with others, because he could not move his body into the film: He moved his mind making relations together with the protagonist.

Margarethe Von Trotta does not follow the Hitchcock's way. She just displays a human condition that everybody empathizes with, even a philosopher, a viewer or a director. In Hannah Arendt then, the empathizing is simply based on the universality of existence.

It seems to be the reason why here we cannot completely think about a classic identification: It is absolutely not static, but in action. Cinema viewers undertake the same action of relation undertaken by the protagonist. They develop each part, "figures" and objects, perceptions, actions, and reactions, historical and social situations. They do it through the "banality of Evil" concept and through the whole integrity that it implies. Cinema viewers are called to put back together the scraps of the History broken line. That is why we cannot talk just about an intellectual participation of the viewer: Here we have a directly called for an intellectual action.

Here is the real contingency of the theoretical construct: its creation movement in the thinking action of a philosopher and in the thinking action of a cinema viewer. 
We can understand now why Hannah Arendt is a philosophical film as no others before. Von Trotta makes an active dialogue between cinema and philosophy thanks to the continuous movement of the mind relation, the protagonist's one and the viewer's one. The "banality of Evil" concept becomes a reflection first, then offers itself to the contemplation and spreads as a communication at last.

Following the protagonist, Von Trotta takes her audience inside the powerful tragedy of the Shoah. She shows how this shook History so that the only way to restart seems to be by a zero-hour of human conscience. The German director highlights this moment through the Arendt thinking offering it to the viewers who can come to a zero-hour of conscience. The viewers' identification with Hannah Arendt allows them to live the historical and cultural situation, making them understand how she thought starting History again.

What we can highlight through our study is that the dialogue between cinema and philosophy can be fulfilled with the Deleuze's movement-image only. Time-image is not operational enough for this realization. This is because thinking is a pragmatic act of mind and philosophy is an intellectual activity: A theoretical construct is a movement. And the reliable representation of it seems to be its concrete implementation in existence.

Von Trotta's Hannah Arendt proves that cinema can put up this representation by having a dialogue with philosophy.

\section{References}

Deleuze, G. (1983). L’image-mouvement, Cinéma 1 (The movement-image, cinema 1). Paris: Les Éditions de Minuit.

Deleuze, G. (1985). L'image-temps, Cinéma 2 (The time-image, cinema 2). Paris: Les Éditions de Minuit.

Palazzi, S. (2004), Gilles Deleuze. Fuori dai cardini del tempo (Time is out of joint). Lezioni su Kant (Cours Vincennes 1978 on www.webdeleuze.com). Milano: Mimesis Edizioni. 